\title{
ANALYSIS OF PANEL DESIGN EXPERIMENTS IN ADVANCED LONGWALL MINES
}

\author{
Seyed Hadi Hoseinie ${ }^{1}$, Behzad Ghodrati ${ }^{2}$
}

Received: September 25, 2020

Accepted: October 30, 2020

\begin{abstract}
Panel design and its geometry affects the productivity, strata control and operational costs of longwall mining. Selection the suitable panel size is a critical stage which needs a wide range of geological, technological and economical inputs. Seam height and overburden are two uncontrollable factors which play an important role in longwall mine design. Panel width, panel length and layout of whole mine are main design parameters which are selected based on uncontrollable factors and technological restrictions. In this paper the geometrical characteristics of 61 longwall panels in 46 operating mines of USA have been applied for statistical analysis and extracting some experimental design benchmarks. The analysis shows that average seam height, panel overburden, panel width and panel length are 2.26, 200, 361.5 and 3455 respectively. Average panel width to depth ratio is 1.53 and panel length to width ratio is 9.55 . The $3 \mathrm{D}$ data analysis reveals that overburden is more important than seam height in enlargement of longwall panels and maximum of the panel area (panel length multiplied by panel width) occurs when the overburden is between 150 to 250 meters and seam height is from 1.5 to 2.5 meters. Also, 50 percent of the studied advanced longwall panels the width to depth ratio varies from one to two. It confirms that even in shallow panels the designers have selected larger panel dimensions to enhance the productivity by considering some subsidence problems and high caving pressures.
\end{abstract}

Keywords: Coal, design, panel width, panel length, overburden

\section{INTRODUCTION}

Longwall is a common and highly productive underground coal mining method. Usually, the selection of the suitable exploitation technology depends on geology, depth or quality of the seams (Lehmann and Konietzky 2016). From operational point of view, longwall is the most continues underground mining method and this is the important feature of this method which should be seriously considered in all mining stages from design to processing. Continuity originally comes from the special geometry of longwall mines which is unique among all mining methods. The mine geometry is built upon the

\footnotetext{
${ }^{1}$ Mining Machinery Laboratory, Department of Mining Engineering, Isfahan University of Technology, Isfahan, Iran

${ }^{2}$ Division of Operation and Maintenance Engineering, Lulea University of Technology, Lulea, Sweden

E-mail: $\underline{\text { hadi.hoseinie@iut.ac.ir }}$
} 
longwall panels' distribution and their dimensions. Coal seam height, panel width, panel length and panel depth (amount of overburden) are key factors which explain the condition of each longwall mine and its panels.

Among the mentioned factors, seam height and overburden are uncontrollable factors; and controllable factors are the panel dimensions including its width and height. These controllable factors are vital in optimization of mine design, face operation and overall production. Selecting the suitable panel dimensions not only affects the operation efficiency but also influences the many mining aspects such as ventilation, stress distribution, safety, operational costs and equipment selection (Mishra et al. 2013, Prasad 2009).

Suitable panel size is depended on four major families of parameters: geotechnical, economical, operational and technological. The interaction of these parameters hardens the decision making for mine designers. However, some geological phenomena like faults and underground water resources might help the designers to limit the mine boundary based on their orientations. Layout of the panels and mining sequence affect the redistribution of ground stresses. Generally, vertical stress concentrations increase with longer panels, also changing the horizontal stresses.

In this paper it is tried to study the longwall panels' dimensions in operating advanced longwall mines. For this purpose, the design characteristics of large American longwall mines and their panel dimensions are statistically analyzed and some benchmarks as experience-sharing are presented.

\section{LONGWALL PANEL DIMENSIONS}

The parameters which control the magnitude and propagation of ground movements can be generally classified into two main categories (Shadbolt 1978, Newman et al. 2001):

- mining factors which are relate to the mining methods,

- $\quad$ geometry and dimensions of the excavation, e.g. seam thickness, panel width and depth, method of support, extracted height, rate of advance, etc.

Seam thickness directly influences the operation costs and production rate. In a thin seams, more extensive workings have to be developed and a greater area of ground has to be mined in order to achieve the same mine output. As a result, those costs related to the extension of extraction are increased. For example, costs for conveyor belts, rail track, water and power lines, haulage of coal, rocks, and supplies, ventilation, entry construction, roadway maintenance, spillage cleaning and rock dusting become higher in thinner coal seams (Li and Topuz 1987, Karacan et al. 2008). 
The level of productivity is influenced by both face width and cutting height. By increasing the width of a longwall panel, the following benefits can be realized (Trackemas and Peng 2013):

- productivity improved because less time is spent in the wedge cuts at end of the faces

- cost reduction of gate road development and the ability to maintain float time

- improved reserve recovery

Along with mentioned advantages, long faces lead the longwall panel to higher production rates which indicate possible adequate mining conditions and specially implementation of longwall automation systems successfully (Khanal et al. 2010).

As a general principle, bigger longwall block sizes are preferred in practice because of following reasons (Mitchell 2009):

- fewer relocating of machinery is required

- lower the total development required per unit of production

- higher amount of available coal to be cut by shearer

- lower capital cost per longwall production

- lower wasted coals in chain pillars

As mentioned earlier, the panel geometry including width and length affects several aspects of longwall mining and is the most important design factor of longwall mine. So far, many researchers have focused on this issue and have reported some experimental field analysis results. Peng (2006) as one of the most well-known researchers in this field has concluded that the most common longwall panel dimensions are about 300 meters wide by about 2500 to 4000 meters long. However, by implementing new technologies and advanced large size machinery, the size of longwall mines and geometry of the panels have also changed. In total, factors which constrain longwall block sizes could be listed as followings (Johnsonm 2013):

- Avoiding the geological structures

- Poor strata control due to slower advance rate

- Difficulties in controlling the alignment and steering of cutting

- Large conveyor installations

- Higher ventilation costs 
- Maintenance challenges of longwall equipment

- Increasing of the initial capital cost

In this article, the geometrical and design parameters of USA's advanced operating longwall mine have been reviewed and statistical analysis have been preformed to find out some experimental geometrical ratios for future longwall mine designs.

\section{DATA BASE FOR STATISTICAL ANALYSIS}

The world's most productive longwalls are located in the USA, Australia and China. Nowadays, some of the mines around the world produce coal between 5 and 10 million tons per longwall face per year. In Australia the best reported output is over 7 million tons from a single longwall face. In the USA, operating longwalls are producing over 175 million tons per year with the best one over 7 million tons per year. It makes the USA as the most reliable longwall operator (Flook and Leeming 2008).

In this article a report of USA coal production in 2015 by Fiscor (2016) has been applied for statistical analysis to extract some experimental information from American longwall panels. This report consists of geometrical parameters of 61 longwall panels in 46 operating mines. Table 1 presents the applied data in a brief format.

\section{STATISTICAL ANALYSIS}

In this section all mentioned parameters in Table 1 are statistically analyzed. For this purpose the best-fitted distribution functions were assigned to each data set and thereafter, regression analysis was carried out to investigate whether there is significant relationships between pairs of geometrical parameters or not? The detailed analysis of mentioned parameters are presented in following sub-sections.

\subsection{Seam height and panel overburden}

The statistical analysis shows that coal seam height in active longwall mines varies from $1.15 \mathrm{~m}$ up to $4.8 \mathrm{~m}$ (Fig. 1). Eighty percent of the longwall panels have less than $2.8 \mathrm{~m}$ seam height. As it seen, the coal seams have $2.26 \mathrm{~cm}$ height in average and most common seam height in USA longwall mines is 1.5 to 2 meters. 

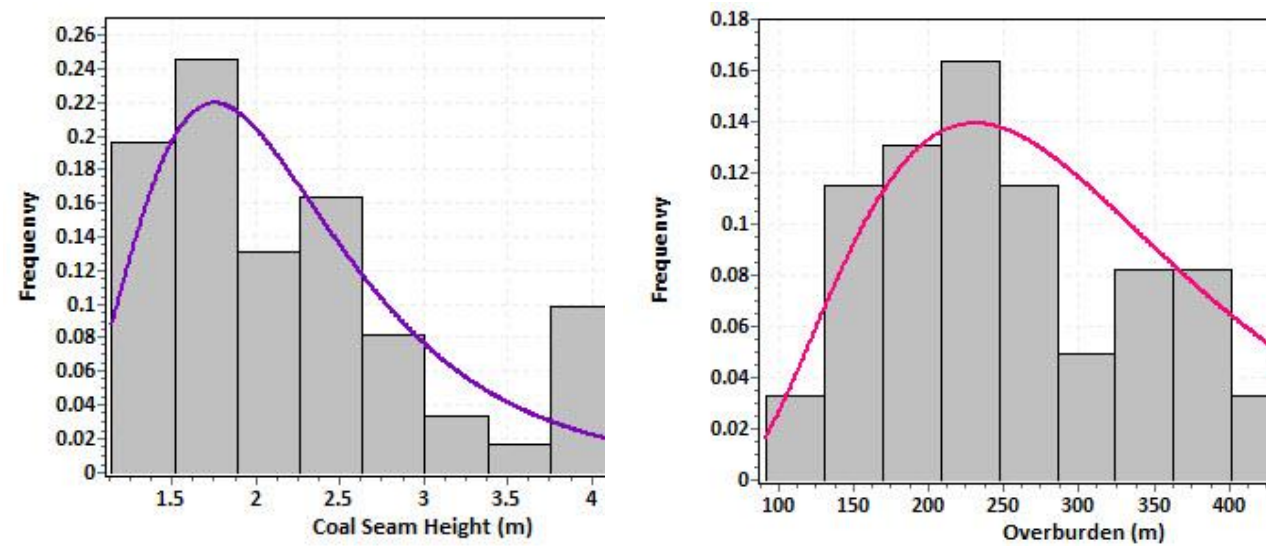

Figure 1 Histogram of coal seam height and overburden in American advanced longwalls

The analysis of overburden of studied mines reveals that the depth of longwall mining is so variable (Fig. 1). In 27 percent of the cases, overburden is less than 200 meter, 50 percent is between 200 to 400 meters and the rest are deeper than 400 meters. The most common depth for longwall mining in is 200 to 250 meters depth by the frequency of 16.5 percent. These panels are generally called "shallow" and strata control within this condition used to be problematic in past decades. Nevertheless, by developing advanced hydraulic power supports and better integration of longwall systems, it has become common to be extracted cost-efficiently.

Table 1 Geometrical data from American longwall panels (adopted from (Fiscor 2016))

\begin{tabular}{lcccc}
\hline Panel Name & $\begin{array}{c}\text { Seam } \\
\text { Height }(\mathbf{m})\end{array}$ & $\begin{array}{c}\text { Panel } \\
\text { Width }(\mathbf{m})\end{array}$ & Panel Length (m) & $\begin{array}{c}\text { Mean } \\
\text { Overburden (m) }\end{array}$ \\
\hline Blue Creek No.4 & 1.1 & 340 & 1220 & 488 \\
Blue Creek No.4 & 1.1 & 340 & 3965 & 488 \\
Blue Creek No.7 West & 1.3 & 323 & 2135 & 488 \\
Blue Creek No.7 West & 1.3 & 323 & 2440 & 488 \\
Blue Creek No.7 East & 1.3 & 317 & 1220 & 488 \\
Blue Creek No.7 East & 1.3 & 317 & 3965 & 488 \\
Oak Grave & 1.3 & 332 & 3752 & 239 \\
Shoal Creek & 2.7 & 305 & 3355 & 351 \\
Bowie Mine No.2 & 4.9 & 258 & 2135 & 427 \\
Deserado & 3.2 & 244 & 3355 & 198 \\
Twentymile & 2.7 & 305 & 3660 & 465 \\
\hline
\end{tabular}


Table 1 Cont. Geometrical data from American longwall panels (adopted from (Fiscor 2016))

\begin{tabular}{|c|c|c|c|c|}
\hline Panel Name & $\begin{array}{c}\text { Seam } \\
\text { Height (m) }\end{array}$ & $\begin{array}{c}\text { Panel } \\
\text { Width (m) } \\
\end{array}$ & Panel Length (m) & $\begin{array}{c}\text { Mean } \\
\text { Overburden (m) } \\
\end{array}$ \\
\hline West Elk & 3.8 & 329 & 3126 & 275 \\
\hline West Elk & 3.8 & 329 & 4880 & 275 \\
\hline Deer Run & 2.4 & 427 & 4575 & 183 \\
\hline Deer Run & 2.4 & 427 & 4880 & 183 \\
\hline Mach Mining & 1.8 & 427 & 5795 & 153 \\
\hline New Era & 1.9 & 412 & 4331 & 177 \\
\hline New Future & 1.9 & 451 & 2227 & 175 \\
\hline Sugar Camp A & 1.8 & 427 & 5795 & 275 \\
\hline Sugar Camp B & 1.8 & 427 & 5948 & 275 \\
\hline Hamilton Country No.1 & 1.9 & 427 & 4423 & 305 \\
\hline Bull Mountains & 3.9 & 381 & 6863 & 160 \\
\hline San Juan South & 4.3 & 305 & 3813 & 198 \\
\hline Century Mine & 1.5 & 458 & 3660 & 153 \\
\hline Powhatan No.6 & 1.5 & 472 & 2593 & 92 \\
\hline Bailey-Dry Ridge & 1.7 & 458 & 3660 & 214 \\
\hline Bailey-Crabapple & 1.7 & 458 & 3660 & 275 \\
\hline Harvey & 1.7 & 458 & 4575 & 336 \\
\hline Cumberland & 2.1 & 482 & 2867 & 275 \\
\hline Enlow Fork-Fside & 1.7 & 458 & 3660 & 214 \\
\hline Enlow Fork-Eside & 1.7 & 458 & 3660 & 214 \\
\hline Sufco No.1 & 3.8 & 339 & 732 & 397 \\
\hline Sufco No.1 & 3.8 & 339 & 1220 & 397 \\
\hline Skyline & 3.6 & 259 & 1830 & 488 \\
\hline Lila Canyon & 3.8 & 162 & 1525 & 305 \\
\hline Buchanan & 1.7 & 214 & 3508 & 519 \\
\hline American Eagle & 1.3 & 311 & 4941 & 183 \\
\hline American Eagle & 1.3 & 311 & 4941 & 305 \\
\hline Sederal No. 2 & 2.4 & 320 & 2593 & 229 \\
\hline
\end{tabular}


Table 1 Cont. Geometrical data from American longwall panels (adopted from (Fiscor 2016))

\begin{tabular}{lcccc}
\hline Panel Name & $\begin{array}{c}\text { Seam } \\
\text { Height }(\mathbf{m})\end{array}$ & $\begin{array}{c}\text { Panel } \\
\text { Width (m) }\end{array}$ & Panel Length (m) & $\begin{array}{c}\text { Mean } \\
\text { Overburden (m) }\end{array}$ \\
\hline Harrison County & 2.3 & 470 & 4240 & 153 \\
Marion County & 2.5 & 470 & 4240 & 244 \\
Marion County & 2.5 & 470 & 4240 & 381 \\
Marshall County A & 1.7 & 458 & 3843 & 153 \\
Marshall County A & 1.7 & 458 & 3843 & 336 \\
Monogalia County & 2.0 & 336 & 3599 & 351 \\
Mountain View & 2.4 & 259 & 1830 & 214 \\
Mountain View & 2.4 & 259 & 2440 & 214 \\
Ohio County & 2.2 & 458 & 3325 & 153 \\
Ohio County & 2.2 & 458 & 3325 & 397 \\
Pinnacle No.50 & 1.2 & 305 & 2745 & 183 \\
Pinnacle No.50 & 1.2 & 305 & 2745 & 397 \\
Ohio County & 2.2 & 458 & 3325 & 397 \\
Tunnel Ridge & 1.7 & 305 & 2745 & 122 \\
Bridger & 3.0 & 183 & 3050 & 214 \\
Green River & 2.9 & 154 & 1525 & 458 \\
Westvaco & 2.9 & 229 & 2867 & 458 \\
\hline & & & & \\
\hline
\end{tabular}

As discussed earlier, seam height and panels' overburden are two uncontrollable factors which are dictated to design of longwall mine. Nevertheless, the large variation in both parameters reveals that a complex decision making process needs to be passed during the panel geometry design to optimize the face productivity and enhance the operation safety.

\subsection{Panel width and panel length analysis}

Panel width is one the most important operational, economical and geotechnical parameters in longwall mines. It is really crucial to select the optimum value for it specially in advanced well-equipped faces. The statistical analysis of available data reveals that in currently operating longwall mines in USA minimum width of panel is 154 meters which is located in mine with the seam height of 2.8 meters and overburden of 457 meters. The maximum panel width has been designed by 482 meters in 
Cumberland mine with the seam height of 2 meters and overburden of 274 meters (Fig. 2). It is seen that just 20 percent of the panels have less than 280 meters width and 36 percent of them are higher than 400 meters. The rest do have panel widths of 200 to 400 meters. In average, the width of American advanced longwall panels is 361.5 meters. The results reveals that, by implementing modern productive longwall equipment specially shearers and powerful hydraulic supports, the designers prefer to increase the panel width as much as possible.

Based on the analysis, panel length is most variable parameter in American longwalls. It varies from 732 meters up to 6800 meters. Nevertheless, the average panel length is about 3455 meters. 15 percent of panels are less than 2000 metros in length, 55 percent are between 2000 to 4000 meters and in 30 percent of panels are called "Giant Panels" the length is over than 4000 meters. In other words, 80 percent of studied panels have the length of less than 4000 meters.

The analysis clearly reveals that if we consider three class of longwall mines as those their overburden is less than 200 meters, with overburden more than 200 and less than 400 meters and the mines with more than 400 meters overburden, a general trends appear (Fig. 2). It is shown that the rate of length increase in mines with less than 400 overburden in almost obey a similar trend and in such mines the relation between width and length of panel is like Equation (1).

$$
\text { Panel Lenght }=112.5 \times(\text { Panel Width })^{0.58}
$$

In deep mines with the overburden of more than 400 meters, the analysis doesn't show any increasing trend and somehow the length of panel is independent from panel width and is values around 4000 meters. 

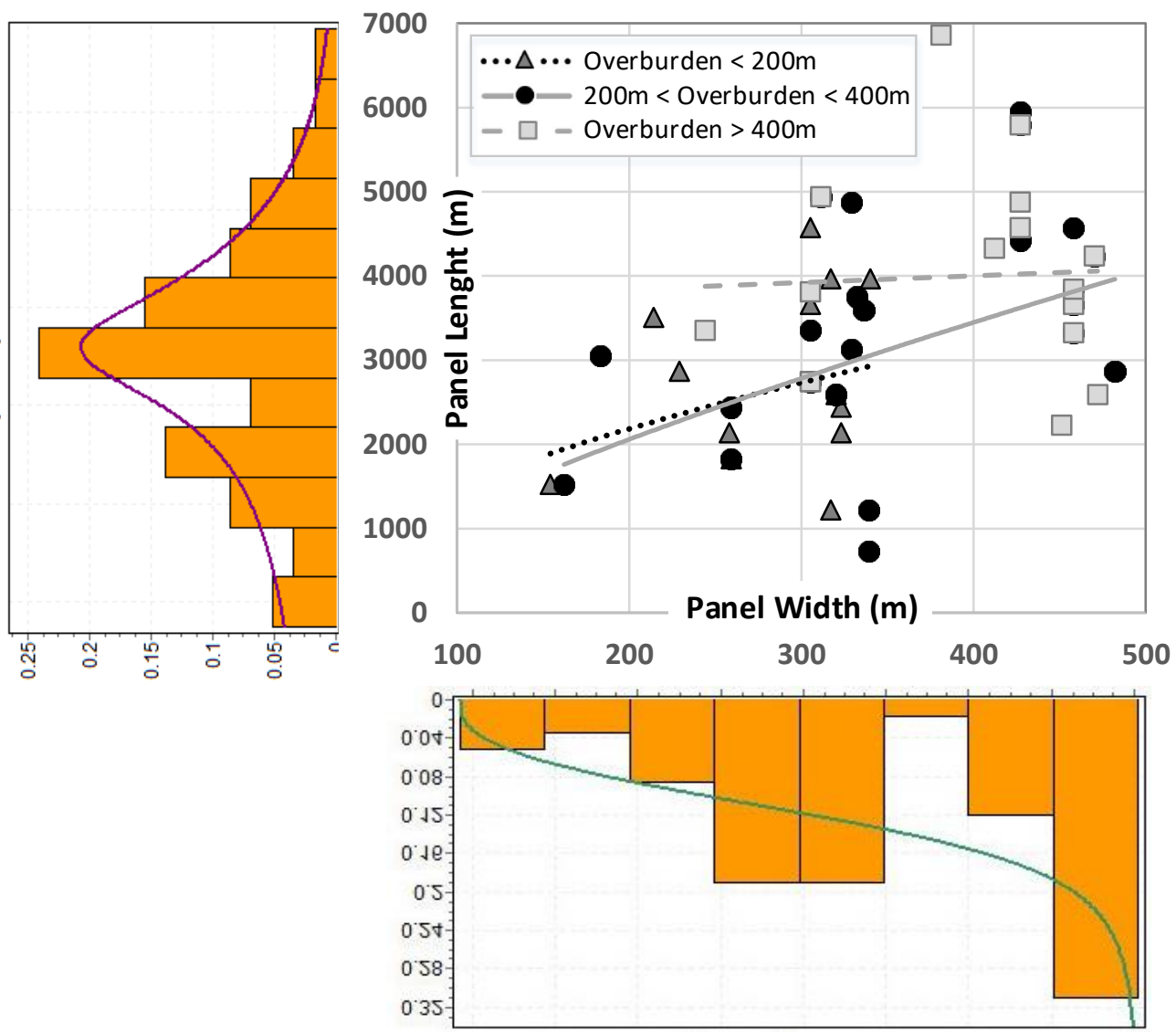

Figure 2 Relationship between panel width and panel length in studied mines considering three different categories of overburdens

\subsection{Width to depth ratio}

The width to depth ratio is defined as the width of the panel divided by the depth of the coal seam. When a critical width to depth ratio is achieved, maximum subsidence will occur. Maximum subsidence for sandstone typically occurs near width to depth ratios of 1.0, whereas for shales and siltstones it occurs near width to depth ratios of 1.4 (Gray and Bruhn 1984, Johnsonm 2013). In the United States, the maximum subsidence is greater than $70 \%$ of the extracted material, and this value is only achieved when the critical width to depth ratio is reached. Therefore, it is essential to consider the width to depth ratio in whole longwall design process not only from production view but also from safety and environmental aspects.

As it is seen in Fig. 3, the width to depth ratio varies from less than one to over five. In eighty percent of operating panels this ratio is less than 2.2 and in 50 percent of the cases is between one to two. It clearly reveals that even in shallow panels the designers have 
selected larger panel dimensions to enhance the productivity. It is due to advanced power supports which make possible to fairly overcome the ground problems and control the subsidence along with selecting the large panel dimensions. In total, just in 30 percent of panels width to depth ratio is less than critical value of one.

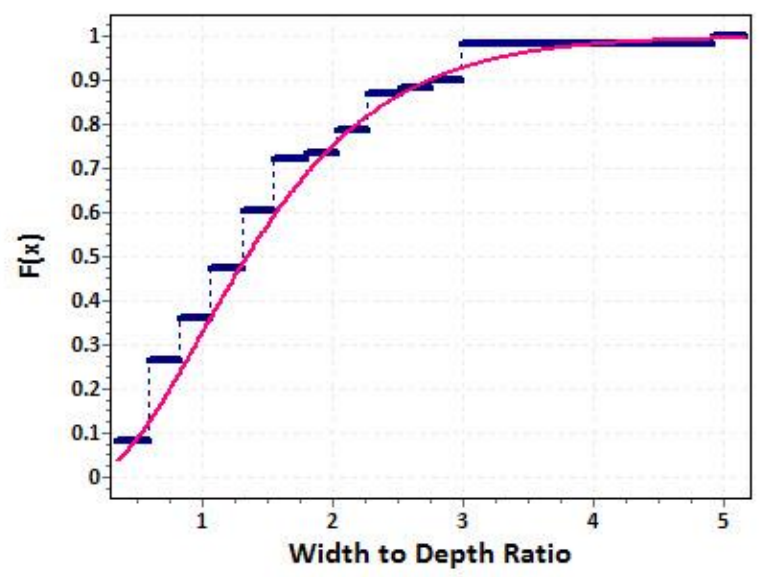

Figure 3 Histogram and cumulative probability plot of width to depth ratio of studied panels in longwall mines

\subsection{Length to width ratio}

Length to width ratio presents the overall shape of panel body. As it is shown in Fig. 4, this ratio varies from almost 2.2 to 16.7 in studied American longwall mines. However, the most popular ratios are period of seven to eleven. It reveals that experimentally the longwall operators have found out that in mentioned rage, economical and operational condition of panels are in acceptable level and fairly fits to available longwall machinery and systems in market.

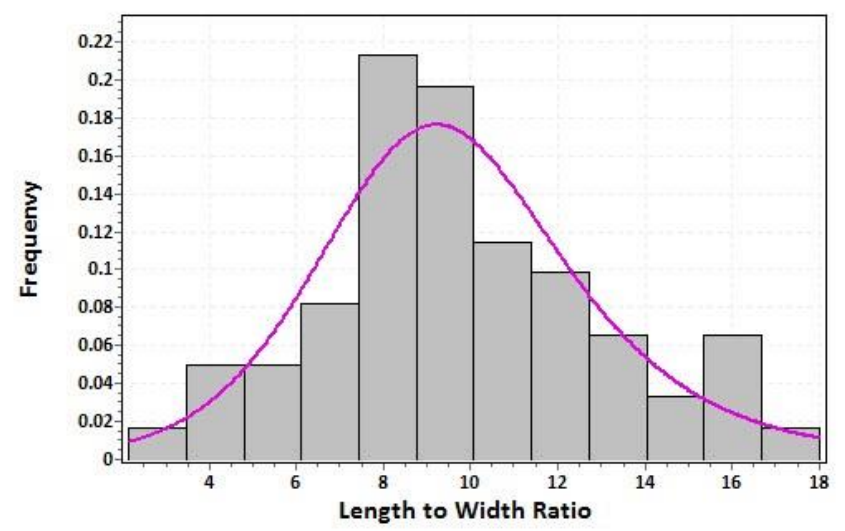

Figure 4 Histogram of length to width ratio of panels in longwall mines 
In Fig. 5 and 6, the 3D plot of coal seam height, overburden and panel width is presented. As shown in this figure, by increasing of the seam height and panel overburden, the panel width increases generally. The figure clearly reveals that overburden is more important than seam height in enlargement of longwall panels. In other view, maximum of the panel area (panel length multiplied by panel width) occurs when the overburden is between 150 to 250 meters and seam height is from 1.5 to 2.5 meters. In other local maximum point, in thick seams (over four meters seam height) the panel area increases considerably even in shallow panels. It is due to strata control and maximizing the net present value (NPV) of involved coal in each panel.

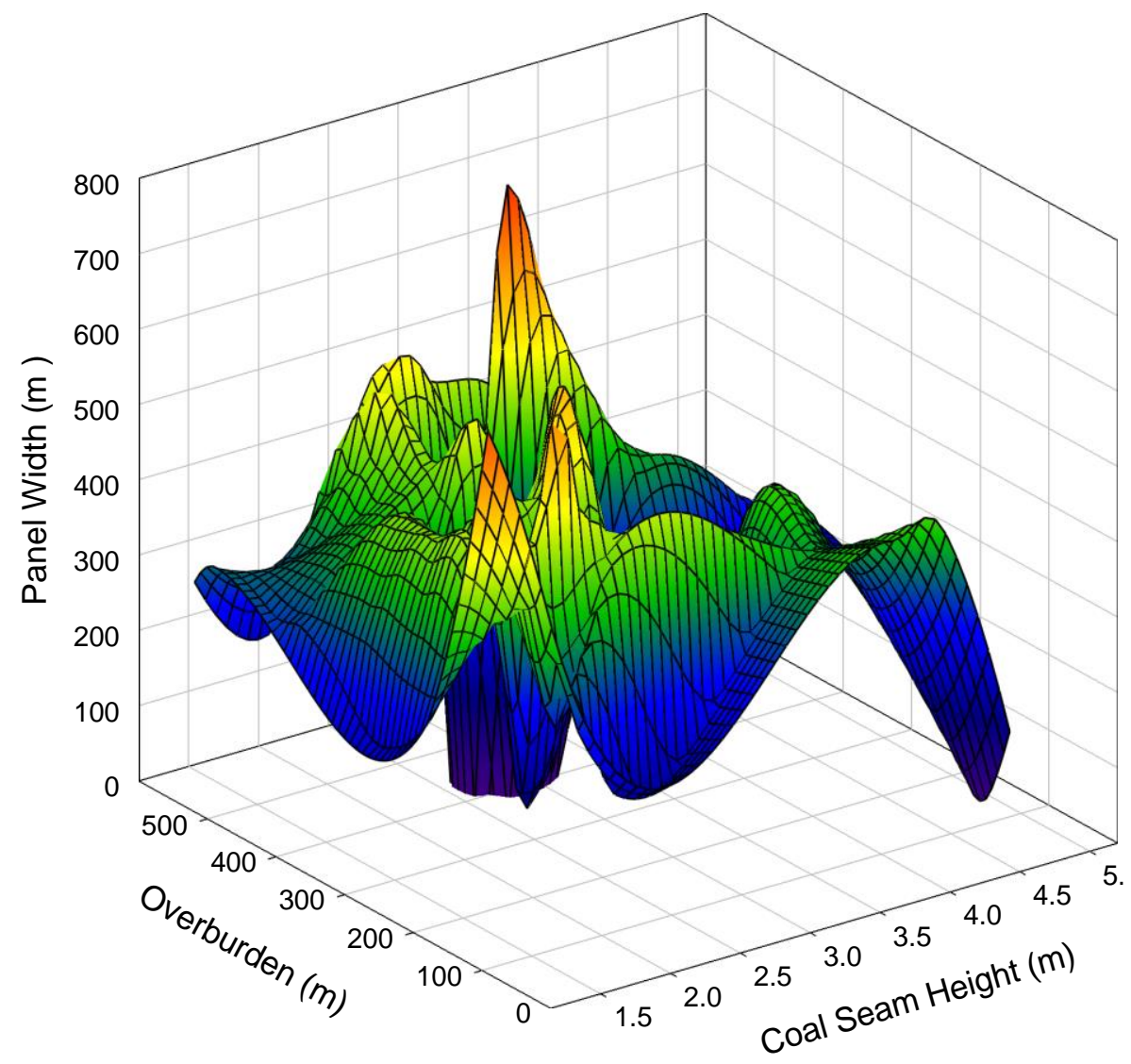

Figure 5 3D plot of coal seam height, overburden and panel width in advanced longwall mines 


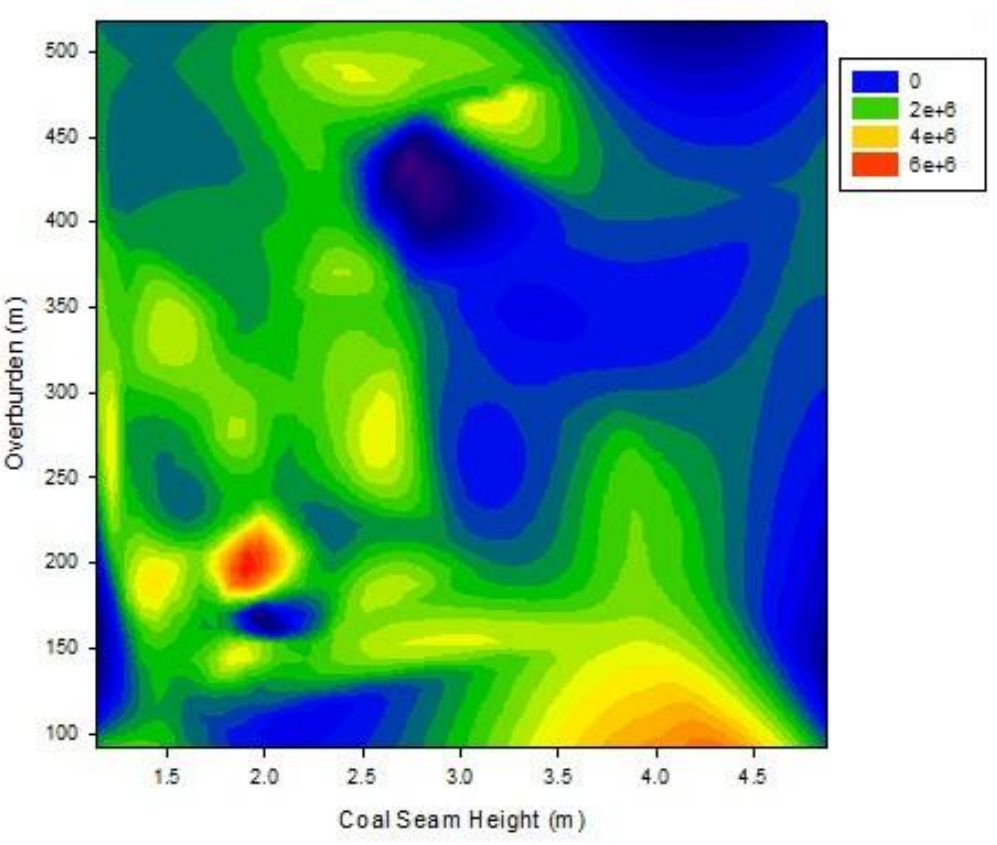

Figure 6 Contour plot of coal seam height, overburden and panel area in advanced longwall mines

\section{CONCLUSION}

In the current paper the operating advanced longwall mines of USA were reviewed based on the available data from 2015. The paper address one of the main design challenges in longwall mine development process which have been attractive for coal engineers and researchers during the several past decades. Within the research, the geometrical features of extraction panels are statistically analyzed and important dimensional ratios were checked out in 61 different panels. Since the studied mines have been designed by different companies with different experimental backgrounds in large-scale longwall mines, the outputs of the article could be a suitable representative of overall design ideas in operating longwall design and scheduling. Along with earlier presented analysis, as a brief summery and experimental benchmarks, the core part of findings of the current paper could be listed as Table 2 . 
Table 2 Summary of design parameters and panel geometry in advanced longwall mines

\begin{tabular}{lccc}
\hline Parameters & Minimum $(\mathbf{m})$ & Maximum $(\mathbf{m})$ & Mean/Common Value \\
\hline Seam height & 1.15 & 4.8 & 2.26 meters \\
Panel overburden & 100 & 550 & 200 to 250 meters \\
Panel width & 154 & 482 & 361.5 meters \\
Panel length & 732 & 6800 & 3455 meters \\
Panel width to depth ratio & 0.33 & 5.16 & 1.53 \\
Panel length to width ratio & 2.16 & 16.67 & 9.55 \\
\hline
\end{tabular}

Combination of the above mentioned geometrical parameters makes the panel design process as a multi-factorial decision making process which involves a lot of geological, operational, economic and environmental aspects which should be considered simultaneously.

In total, the analysis shows that a typical advanced longwall panel is large block of coal with length to width ratio of almost 10 and its largest area is happen when the overburden is between 150 to 250 meters and seam height is from 1.5 to 2.5 meters. The analysis shows that in shallow and medium depth mines (overburden $<400 \mathrm{~m}$ ) the panel length in increased based on a smooth power function, nevertheless, in deep panels (overburden $>400 \mathrm{~m}$ ), the length of panel is more or less independent from panel width and has been designed to be around the $4000 \mathrm{~m}$ in operating mines.

Finally, the presented benchmarks for advanced longwall panels could be assumed as a preliminary design values for development of a systematic rock mechanical, economical, operational and safety analysis and are just present a start point of thinking.

\section{REFERENCES}

FISCOR, S. (2016) US Longwall operators scale back production, Coal Age, February 2016, pp. 18-22.

FLOOK, SD., LEEMING, JJ (2008) Recent developments in longwall mining entry development, and room and pillar systems, Gospodarka Surowcami Mineralnymi, Vol.24, pp. 11-21.

GRAY, RE., BRUHN, RW. (1984) Coal mine subsidence-eastern United States, Man Induced land subsidence, 6: pp. 35-66. 
JOHNSONM, CP. (2013) A Guide to Surface Features Related to Underground Coal Mining, MSc Thesis, Applied Geosciences, University of Washington, December 2013.

KARACAN, CO., DIAMOND, WP., ESTERHUIZEN, GS., SCHATZEL, SJ. (2008) Numerical Analysis of the Impact of Longwall Panel Width on Methane Emissions and Performance of Gob Gas Ventholes, National Institute for Occupational Safety and Health (NIOSH), Pittsburgh Research Laboratory, USA.

KHANAL, M., ADHIKARY, D., BALUSU, R. (2010), Assessment of Chock Capacity and Strata Caving for a Longwall Mine, Earth Science and Resource Engineering, Commonwealth Scientific and Industrial Research Organization, CSIRO, Queensland Center for Advanced Technology, Australia, 18 pages.

LEHMANN, C., KONIETZKY, H. (2016) Geomechanical issues in longwall mining-an introduction, TU Bergakademie Freiberg, Geotechnical Institute, pp. 22.

LI, Z., TOPUZ, E. (1987) Optimizing design capacity and field dimensions of underground coal mines. APCOM 87. Proceedings of the 20th International Symposium on the Application of Computer and Mathematics in the Mineral Industries. Volume I: Mining. Johannesburg. SAIMM. 1987. pp. 115 - 122.

MISHRA, DP, SUGLA, M., SINGHA, P. (2013) Productivity Improvement In Underground Coal Mines - A Case Study, Journal of Sustainable Mining, Vol. 12, No. 3 , pp. 48-53.

MITCHELL, GW. (2009) Longwall Mining, Monograph 12- Australasian Coal Mining Practice. Available online at: http://www.undergroundcoal.com.au/longwall

NEWMAN, D., AGIOUTANTIS, Z., KARMIS, M. (2001) SDPS for Windows: An Integrated Approach to Ground Deformation Prediction, 20th International Conference on Ground Control in Mining, August 7-9, 2001, West Virginia, USA.

PEN, S. (2006) Longwall Mining, 2nd Edition, Morgantown, W.Va: West Virginia University, USA, 620 pages.

PRASAD, M. (2009) Underground coal mining, the way ahead. Available online at: http://www.projectsmonitor.com/detailnews.asp?newsid=17688

SHADBOLT, CH. (1978) Mining Subsidence-Historical Review and State of the Art, Proceedings of Conference on Large Ground Movements and Structures, Cardiff, Wales, pp. 705-748.

TRACKEMAS, JD., PENG, S. (2013) Factors considered for increasing longwall panel width, Coal Age, August 2013, pp. 32-42. 